\title{
Beyond Lithium in the Treatment of Bipolar Illness
}

\author{
Robert M. Post, M.D., Mark A. Frye, M.D., Kirk D. Denicoff, M.D., Gabriele S. Leverich, L.C.S.W.,
} Tim A. Kimbrell, M.D., and Robert T. Dunn, M.D.

Dramatic changes have recently occurred in the availability of treatment options for bipolar illness. Second generation mood stabilizing anticonvulsants carbamazepine and valproate are now widely used as alternatives or adjuncts to lithium. High potency benzodiazepines are also used as alternatives to typical neuroleptics, and now atypical neuroleptics are demonstrating efficacy and better sideeffects profiles than the typicals. Thyroid augmentation strategies and dihydropyridine L-type calcium channel blockers require further clinical trials to define their role. Putative third generation mood stabilizing anticonvulsants lamotrigine, gabapentin, and topiramate have unique mechanisms of action and deserve further systematic study, as does the potential role for nonconvulsive brain stimulation with repeated transcranial magnetic stimulation (rTMS). These and a host of other potential treatment options now require a new generation of clinical trials to help identify clinical and biological markers of response and optimal use alone and in complex combination therapeutic regimens. [Neuropsychopharmacology 19:206-219, 1998] Published by Elsevier Science Inc.
KEY WORDS: Carbamazepine; Valproate; Calcium channel blockers; Lamotrigine; Gabapentin; rTMS

There is increasing recognition of the inadequacy of "lithium treatment" in bipolar illness, even with adjunctive antidepressants and neuroleptics (Maj et al. 1989; Aagaard and Vestergaard 1990; O'Connell et al. 1991; Vestergaard 1992; Gitlin et al. 1995). Some bipolar patient subtypes are particularly prone to lithium nonresponsiveness; among these are patients with dysphoric mania and rapid cycling; a negative family history for bipolar illness in first-degree relatives; the episode sequence pattern of depression-mania-well interval (i.e., the D-M-I pattern as opposed to the M-D-I pattern); more than three episodes prior to the initiation of prophylaxis (Sarantidis and Waters 1981; Gelenberg et

From the Biological Psychiatry Branch, National Institute of Mental Health, Bethesda, Maryland, USA.

Address correspondence to: Robert M. Post, M.D., Chief Biological Psychiatry Branch, NIMH, Bldg. 10, Room 3N212, 10 Center Drive MSC 1272, Bethesda, Maryland 20892-1272, USA.

Received February 23, 1998; accepted February 23, 1998. al. 1989; O'Connell et al. 1991; Denicoff et al. 1997); a history of co-morbid substance abuse; and those patients with a history of head trauma or other such medical co-morbidities as multiple sclerosis, etc.

In addition, it is recognized that patients with initial excellent responses to lithium can begin to develop breakthrough episodes in subsequent extended years of follow-up (Maj et al. 1989; Post et al. 1992). In our series of 66 lithium-refractory patients, $23(34.9 \%)$ seem to have developed their lithium-refractoriness over more prolonged periods of follow-up, in a pattern resembling tolerance.

Another recently described route to refractoriness has been found in patients who were excellent responders to lithium, but then discontinued treatment (on the basis of either noncompliance or physician acquiescence), experienced a relapse, and then failed to rerespond once lithium was reinstituted (Post et al. 1992, 1993; Koukopoulos et al. 1995). This type of lithium discontinuation-induced refractoriness can be quite malignant, with patients failing to re-respond, even when lithium is augmented with a variety of the other alter- 


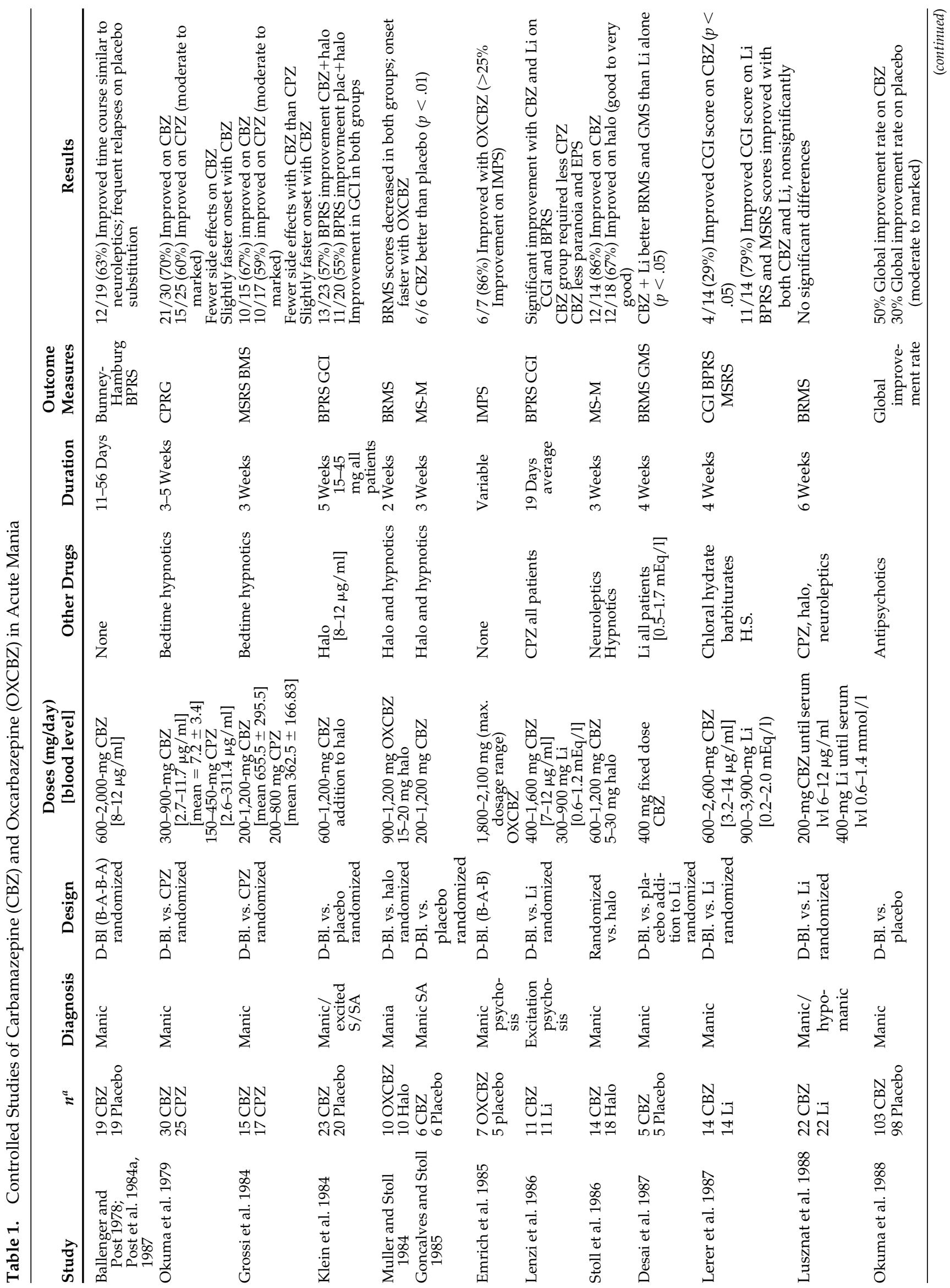




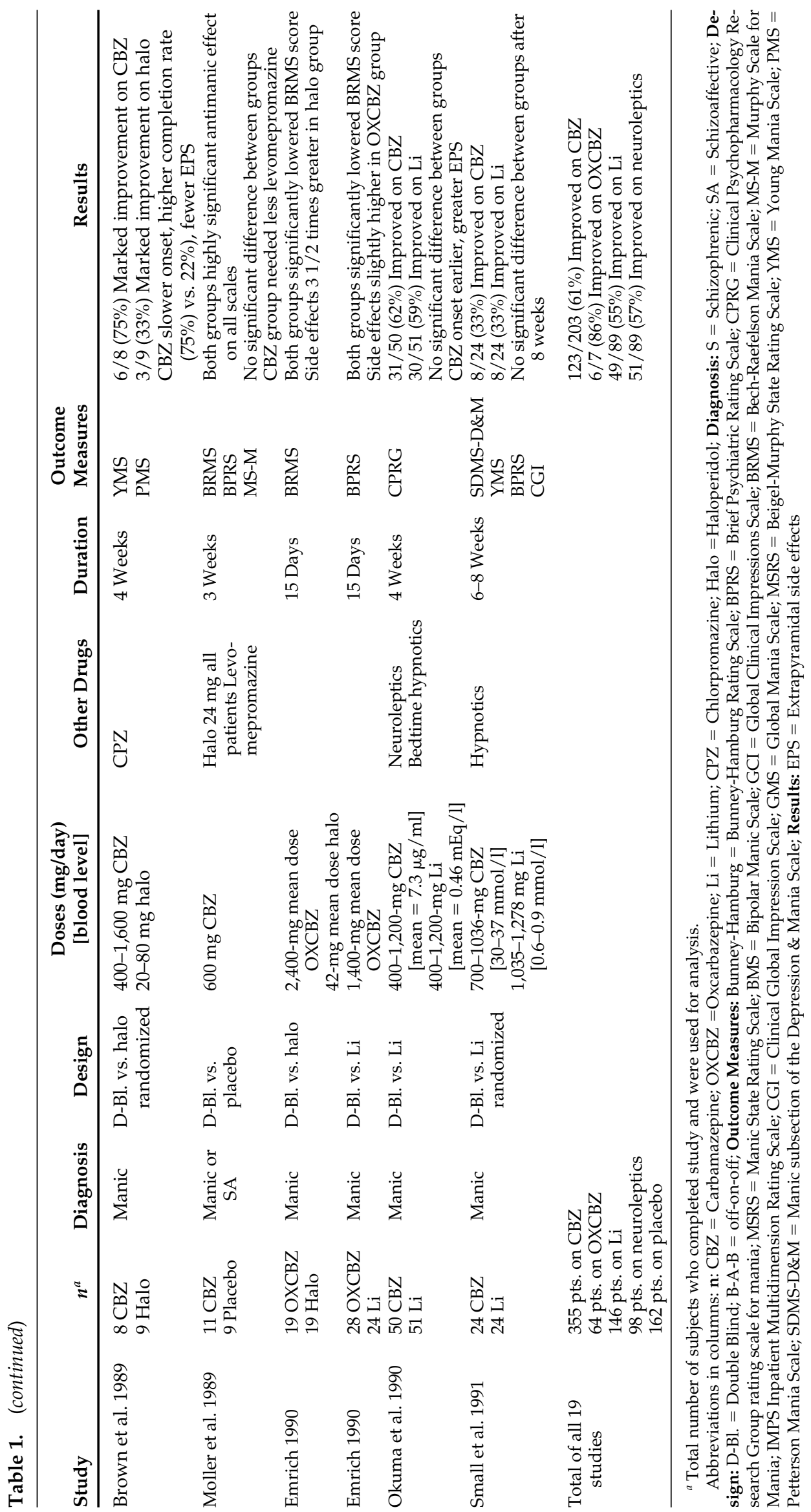


native treatments described below; or more mild, and just require greater neuroleptic augmentation.

Thus, lithium shows parallels to the role of penicillin in the treatment of infectious diseases. Penicillin was initially heralded as a miracle drug (which it was), until patterns of nonresponse or treatment-resistance emerged, and a variety of alternative treatments were required. In cases of tuberculosis or AIDS-related opportunistic infections, for example, patients can require complex combination therapy to bring these more malignant infections under control. A similar sequence of adjuncts and alternatives to lithium treatment is now required for many patients with lithium nonresponsive affective illness.

Some of these emerging alternatives are described below, two of which (the mood-stabilizing anticonvulsants carbamazepine and valproate) have already gained wide acceptance in clinical practice. Valproate recently has been FDA-approved for first-line treatment of acute mania. Many of the other promising approaches are more investigational, but, in many instances, clinical practice is again ahead of more formal controlled clinical trials.

\section{CARBAMAZEPINE}

Nineteen double-blind studies of various methodologies compared with placebo $(N=5)$, compared with neuroleptics $(n=6)$, compared with lithium $(n=6)$, and B-A-B-A (off-on-off-on) designs $(n=2)$ document the acute antimanic efficacy of carbamazepine or its congener oxcarbazepine (Table 1). Perhaps most revealing is the clear documentation of responsivity in individual patients using double-blind, placebo substitution designs that demonstrate efficacy, reconfirmed with placebo-related exacerbation and re-responsiveness after drug institution on a blind basis (Ballenger and Post 1978; Post et al. 1984a; Post et al. 1996a). Antidepressant effects are much less well documented and require further controlled study (Post et al. 1994). However, in long-term prophylaxis, the ability of carbamazepine to prevent recurrent depressive episodes seems as prominent as the ability to prevent recurrent manias in both controlled and partially controlled double-blind studies as well as in open studies (Table 2), with an overall moderate to marked response rate of approximately $62 \%$. Although many of these double-blind studies have been criticized on methodological grounds, other designs used, such as mirror image designs in treatment-refractory patients and B-A-B-A designs, have been cited by Prien and Gelenberg (1989) as more convincing.

As with lithium, a subgroup of patients who are initially responsive to carbamazepine alone or with adjunctive treatment with other agents seems to lose efficacy with the development of tolerance (Post et al. 1990; Leverich et al. unpublished data 1998). Loss of respon- siveness may have accounted for the large drop-out rate in the follow-up study of Frankenburg et al. (1988), although the percentage attributable to tolerance is unknown.

In our prospective follow-up of initial responders, 13 of the 29 carbamazepine responders (45\%) followed in long-term prophylaxis for an average of 6.9 years developed a loss of efficacy after an average of 2.8 years of carbamazepine treatment (Leverich et al. unpublished data). This high percentage may be unrepresentative of the general population because of the relatively treatment-refractory and rapid-cycling nature of the patients who were started on carbamazepine in the acute inpatient phase of this study. However, it would seem that at least a subgroup of patients may develop tolerance to carbamazepine in the treatment of bipolar illness, similar to the even higher percentage of tolerance development using carbamazepine in the treatment of trigeminal neuralgia (Fromm and Terrence 1987).

Weiss et al. (1995a) have described some of the potential molecular mechanisms involved in the loss of anticonvulsant efficacy to carbamazepine in the treatment of amygdala-kindled seizures in rodents. These data suggest that tolerance to carbamazepine is pharmacodynamic rather than pharmacokinetic and may represent the loss of illness-induced adaptations during carbamazepine treatment. As such, these preclinical data would suggest the potential utility of switching to drugs with different mechanisms of action or returning to carbamazepine after a time-off period. Several cases studies support the possibility of the usefulness of such a maneuver (Pazzaglia and Post 1992; and unpublished data), although larger long-term prospective studies are required in order to develop the optimal intervention paradigms for the treatment of carbamazepine tolerance.

In patients who remain successfully treated with carbamazepine, there does not seem to be a very high rate of discontinuation-related refractoriness as observed with lithium; all 10 patients re-responded during a second double-blind trial. However, one schizoaffective patient who showed a rapid antimanic re-response remained psychotic for a longer period (Post et al. unpublished observations). On this issue, as well, longer-term studies in a larger number of patients are required in order to assess this potential liability more definitively across different psychotropic medications.

The clinical predictors of response to carbamazepine have not been adequately delineated. However, there is preliminary evidence that, as in lithium treatment, rapid-cycling patients do not respond as well to carbamazepine monotherapy as do nonrapid-cycling patients (Okuma 1993; Denicoff et al. 1997); whereas, those with a negative family history for bipolar illness in first-degree relatives may be included among those responsive to carbamazepine (Post et al. 1987), as are those with more severe and discrete episodes of depres- 
Table 2. Controlled and Partially Controlled Studies of Carbamazepine (CBZ) and Oxcarbazepine Prophylaxis in Affective Illness

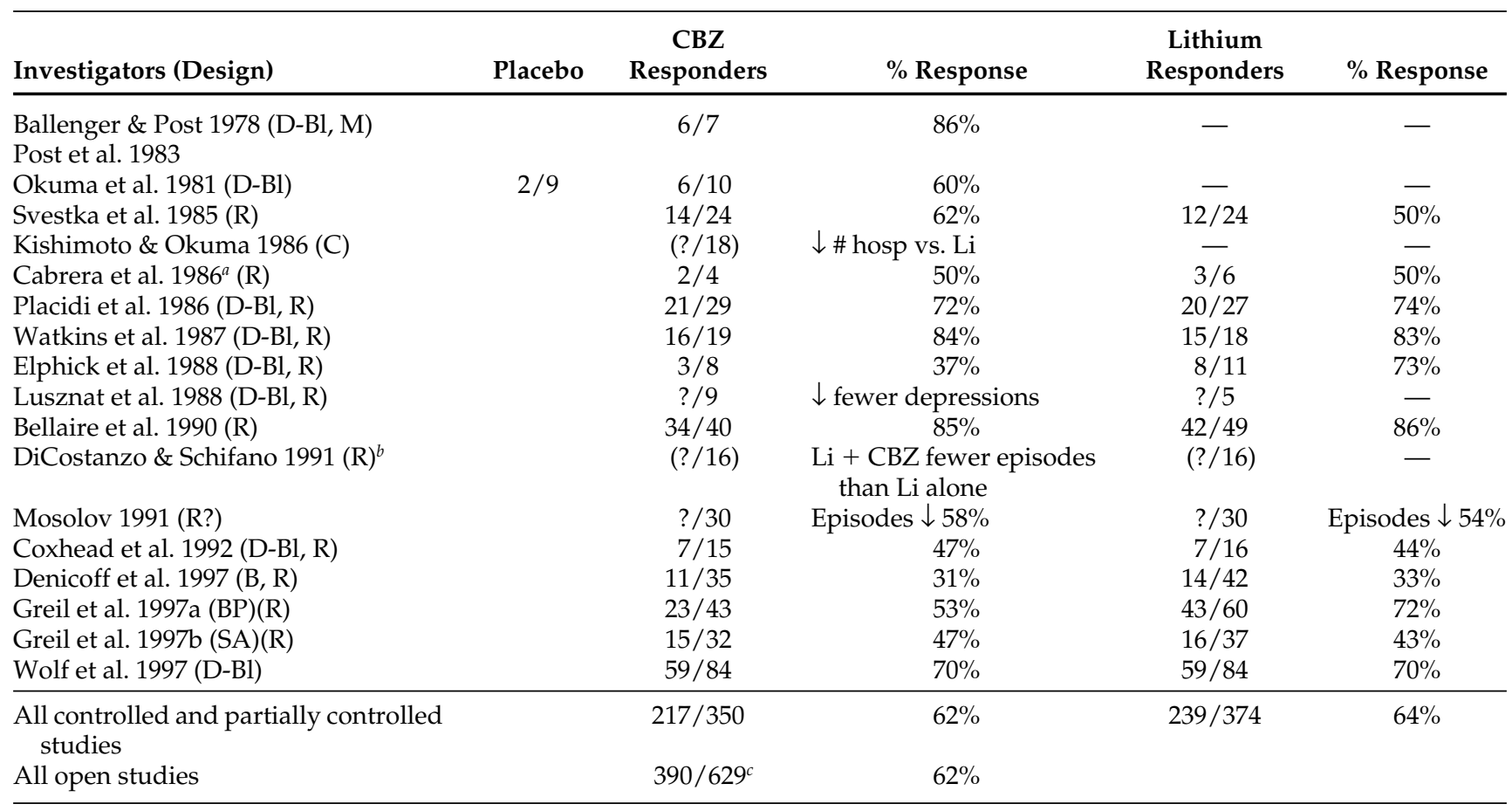

Abbreviations: double-blind (D-Bl), Crossover (C), Mirror image (M), or Randomized (R), (一) not stated; Bipolar (BP), Schizoaffective (SA).

${ }^{a}$ Oxcarbazepine.

${ }^{b}$ Pseudo randomized to Li vs. CBZ \& Li; greater antimanic and antidepressant efficacy in first year vs. Li alone.

${ }^{c}$ Includes carbamazepine combination therapies.

sion and those who have greater decrements in $T_{4}$ and free $\mathrm{T}_{4}$ during treatment with the drug (Roy-Byrne et al. 1984; Post et al. 1986). In the study of Denicoff et al. (1997), the combination of lithium and carbamazepine proved much more effective for rapid-cycling patients than monotherapy with either agent. Ketter et al. (1996) found that patients with global hypermetabolism, and particularly in the region of the left insula, seem more responsive to carbamazepine as compared with depressed patients with a more classical picture of frontal lobe or left insula hypometabolism. It is these latter patients with the typical depressive pattern of frontal hypometabolism who seem more responsive to the dihydropyridine L-type calcium channel blocker nimodipine.

\section{VALPROATE}

Valproate is now FDA-approved for the treatment of acute mania based on several placebo-controlled clinical trials demonstrating efficacy (Pope et al. 1991; Bowden et al. 1994). However, in the study of Bowden et al., only $50 \%$ of the patients showed a $50 \%$ or greater response at the end of the 3-week study, findings in parallel with those of lithium. These data indicate that although valproate is highly effective as compared with placebo, many patients remain inadequately responsive and re- quire adjunctive medications in order to optimize either the time frame or completeness of clinical response.

In this regard, Keck et al. (1993) have used loading doses of valproate $(20 \mathrm{mg} / \mathrm{kg} /$ day $)$ from the beginning of treatment and find it generally well tolerated and able to achieve higher blood levels more readily. This is convergent with the data of Bowden et al. (1996), indicating that patients with blood levels over $45 \mu \mathrm{g} / \mathrm{ml}$ were better early responders to valproate. Open studies by a variety of investigators indicate that valproate has prophylactic effects against recurrences of both acute mania and acute depression in a variety of patients subgroups, including those with dysphoric mania, rapid cycling, and a variety of other traditionally inadequately treated subgroups of bipolar patients (Lambert 1984; Emrich et al. 1984; Fawcett 1988; Calabrese and Delucchi 1989, 1990; Post 1989; Schaff et al. 1993; Lambert and Venaud 1995).

In particular, we and others have noted many patients with excellent responses to valproate who previously were unresponsive to both lithium and carbamazepine. Conversely, we have observed some patients who responded to carbamazepine but failed valproate (Post et al. 1984b), further suggesting that response or nonresponse to one anticonvulsant is not necessarily predictive of responsivity to another (Calabrese et al. 1992; Schaff et al. 1993). 
In our initial series of 27 patients followed for an average of 5.8 years, we observed that four of $15(27 \%)$ initial responders developed a pattern consistent with a loss of efficacy via tolerance after an average of 2.9 years of valproate treatment (Post et al. unpublished data), and McElroy et al. (personal communication) have also reported a small percentage of patients with loss of efficacy to valproate. Clinical predictors and therapeutic maneuvers remain to be more definitively delineated.

\section{CALCIUM CHANNEL BLOCKERS}

A substantial, but partially mixed, literature review supports the use of verapmil in acute mania (Table 3), although several recent studies do not support this perspective (Janicak et al. 1994; Walton et al. 1996). Even the positive double-blind series of Hoschl and Kozeny (1989) in acute mania was unable to demonstrate significant acute antidepressant effects. In light of this ambiguous profile and less than satisfactory response in acute depression, we elected to study a different calcium channel blocker with a different profile of physiochemical and biochemical properties-the dihydropyridine L-type calcium channel blocker nimodipine.

Nimodipine has greater lipid solubility and better penetration into the central nervous system (Freedman and Waters 1987) and is reported to be problematic with tolerance in the treatment of migraine as compared with other calcium channel blockers. Moreover, nimodipine has a different profile of anticonvulsant effects in animal models and, in contrast to verapamil, blocks cocaine-induced hyperactivity and its associated dopamine overflow (Pani et al. 1990).

Five of the first 12 patients treated with nimodipine showed clinically relevant improvement using a double-blind B-A-B, and in some instances, B-A-B-A placebo-substitution design (Pazzaglia et al. 1993). Using this design, response could be confirmed in patients with very different cycle frequencies, and appropriate statistical techniques could be applied in single-case analyses, as described by McDermut et al. (1995).

In an extension of the original study of Pazzaglia et al. (1993), we have now studied a total of 36 patients on nimodipine, 30 of whom were evaluable. Ten of these patients showed clinically relevant degrees of response as rated by marked to moderate response on the clinical global impressions scale (CGI) and confirmed by appropriate within-patient statistical analyses (Pazzaglia et al. 1998). Fourteen patients with an incomplete or inadequate response to nimodipine monotherapy were given a trial of blind carbamazepine augmentation. Four of these showed a clinically significant degree of improvement with the addition of carbamazepine as rated by the CGI change score and confirmed with $t$-tests.
Many of the responsive patients had failed multiple clinical trials of more traditional treatments, including lithium and a variety of other mood-stabilizing and antidepressant modalities. Among these were several patients with ultrarapid and ultra-ultrarapid (ultradian) cycling and several patients with recurrent brief depression. Several of the bipolar patients on either nimodipine monotherapy or combination therapy with carbamazepine were switched from the dihydropyridine nimodipine to the phenylalkylamine verapamil on a blind basis and failed to maintain their same degree of clinical improvement. On a blind basis, they re-responded to nimodipine and continued to maintain this degree of improvement with the transition to another dihydropyridine, isradipine. These data suggest that, at least in these few bipolar patients, there may not be a cross responsivity among all of the L-type calcium channel blockers. The dihydropyridines, with their different site of action inside the calcium channel and different biochemical properties (Triggle 1992), may be preferable to the phenylalkylamines. However, a more formal comparable clinical trial in larger numbers of patients is required to confirm these differential preliminary observations in a few patients with confirmed responses.

\section{LAMOTRIGINE}

This newly approved anticonvulsant for adjunctive therapy in refractory epilepsies has received attention in the treatment of bipolar illness. Lamotrigine has interesting clinical properties including inhibition of excitatory amino acid release and blockade of sodium channels (Messenheimer 1995). However, evidence indicates that lamotrigine may possess other actions not shared by carbamazepine (Brodie et al. 1995), because of its additional efficacy in inadequate responders to carbamazepine in both epilepsy studies and affective illness studies, as described below.

Calabrese (1996) reported a $69 \%$ response rate when lamotrigine was added to previously ineffective treatments for patients with recurrent affective illness and, in a few cases, used in monotherapy. Particularly good responses to depression were noted and showed a relatively rapid onset, including 27 of $39(69 \%)$ in the first week or two of treatment with the 25-mg dose. This low dose was initiated and fully titrated to average doses of approximately $150 \mathrm{mg} /$ day to avoid the reported high incidence of rash.

Relatively similar degrees of response have been observed by Frye et al. (1998) in our group in the initial patients entering a 6-week randomized comparison of lamotrigine to placebo and gabapentin. Seventeen of 33 (52\%) patients responded to lamotrigine as marked or moderate on the CGI-BP. Again, both antidepressant and mood-stabilizing properties were evident in these pa- 
Table 3. Calcium Channel Blockers in Affective Illness

\begin{tabular}{|c|c|c|c|}
\hline Open Studies & Responders & Blind Studies & Responders \\
\hline \multicolumn{2}{|c|}{$\begin{array}{c}\text { Verapamil } \\
\text { (Phenylalkylamine) }\end{array}$} & \multicolumn{2}{|c|}{$\begin{array}{c}\text { Verapamil } \\
\text { (Phenylalkylamine) }\end{array}$} \\
\hline Gitlin \& Weiss 1984 & 1/1 BP & Dubovsky et al. 1982 & $1 / 1 \mathrm{M}$ \\
\hline Brotman et al. 1986 & $6 / 6 \mathrm{M}$ & Dubovsky \& Franks 1983 & $2 / 2 \mathrm{M}$ \\
\hline Solomon \& Williamson 1986 & $2 / 2 \mathrm{M}$ & $\begin{array}{l}\text { Giannini et al. } 1984 \\
\text { Giannini et al. } 1987\end{array}$ & $\begin{array}{l}10 \mathrm{M} \text { Equal to lithium, better than placebo } \\
20 \mathrm{M} \text { Equal to lithium }\end{array}$ \\
\hline Walton et al. 1996 & ?M & Giannini et al. 1989 & $\begin{array}{l}10 \mathrm{M} \text { equal to lithium, better than } \\
\text { valproate }\end{array}$ \\
\hline Barton \& Gitlin 1987 & $\begin{array}{l}0 / 8 \mathrm{M} \text { (Acute) } \\
1 / 4 \mathrm{M} \text { (Prophyl) } \\
2 / 2 \mathrm{M}^{a}\end{array}$ & Dubovsky et al. 1985 & $1 / 1 \mathrm{M}^{a}$ \\
\hline Patterson 1987 & $1 / 1 \mathrm{M}$ & Dose et al. 1986 & $7 / 8 \mathrm{M}$ \\
\hline Pollack \& Rosenbaum 1987 & 1/1 UP & Dubovsky et al. 1986 & 5/7 M vs. $1 / 7 \mathrm{Li}$ \\
\hline Deicken 1990 & $1 / 1 \mathrm{BP}$ & Dubovsky \& Franks 1987 & $\begin{array}{l}1 / 2 \mathrm{M} \\
\text { Using Li-verap comb }\end{array}$ \\
\hline Hoschl et al. 1992 & $\begin{array}{l}4 \text { BP-Dep/7 UP } \\
\text {-verap more effective } \\
\text { than antidep. and } \\
\text { neurolep. }\end{array}$ & $\begin{array}{l}\text { Hoschl \& Kozeny } 1989 \\
\text { Garza-Trevino et al. } 1990 \\
\text { Garza-Trevino et al. } 1992 \\
\text { Hoschl } 1983 \\
\text { Janicak et al. } 1994\end{array}$ & $\begin{array}{l}12 \mathrm{M} \text { Sig. improved over neuroleptics, } \\
\text { neuro }+\mathrm{Li} \\
17 \mathrm{M} \text { Equal to } \mathrm{Li} \\
12 \mathrm{M} \text { Equal to } \mathrm{Li} \\
1 / 1 \mathrm{Dep} . \\
\text { 3/10 vs. } 1 / 11 \mathrm{Li}\end{array}$ \\
\hline
\end{tabular}

Nimodipine (Dihydropyridine)

\begin{tabular}{|c|c|}
\hline Brunet et al. 1990 & $6 / 6 \mathrm{M}$ \\
\hline Manna $1991^{b}$ & $\begin{array}{l}12 \mathrm{M} \text {-greatest improv. } \\
\text { with } \mathrm{Li}+\text { Nimod, vs. Li } \\
\text { alone or Nimod alone }\end{array}$ \\
\hline Goodnick 1995 & $2 / 2 \mathrm{BP}$ \\
\hline Grunze et al. 1996 & $\begin{array}{l}\text { 1/1 BP } \\
\text { (Li + Nimod) }\end{array}$ \\
\hline Walden et al. 1994 & 6/7 Dep. \\
\hline
\end{tabular}

\section{Flunarizine
(Dihydropyridine) \\ Flunarizine
(Dihydropyridine)}

Nimodipine (Dihydropyridine)

$\begin{array}{ll}\text { Pazzaglia et al. 1993; 1998 } & 7 / 23 \text { BP } \\ & 0 / 4 \text { UP } \\ \text { McDermut et al. 1995 } & \text { 3/3 RBD } \\ \text { Eckmann, 1985a (2) } & \text { 27/30 Dep } \\ & \text { 29/30 Dep }\end{array}$

Montenegro et al. 1985

Ban et al. 1990
22/37 able to D/C with amitriptyline or nimodipine vs. $1 / 38$ able to $\mathrm{D} / \mathrm{C}$ on placebo

87 patients on nimodipine, 88 patients on placebo - in elderly patients with cognitive decline, sig. more favorable changes in depressive symptomatology with nimodipine

Flunarizine

(Dihydropyridine)

\begin{tabular}{|c|c|c|c|}
\hline Lindelius \& Nilsson 1992 & $1 / 1 \mathrm{M}$ & \multirow[t]{2}{*}{ Eckmann 1985b } & \multirow{2}{*}{$\begin{array}{l}\text { 14/17 Dep } \\
\text { Isradipine } \\
\text { Dihydropyridine) }\end{array}$} \\
\hline $\begin{array}{r}D \\
\text { (Benz }\end{array}$ & $\begin{array}{l}\text { zem } \\
\text { azepine) }\end{array}$ & & \\
\hline Caillard 1985 & $5 / 5 \mathrm{M}$ & $\begin{array}{l}\text { McDermut et al. } \\
\text { Pazzaglia et a }\end{array}$ & 2/2 BP Nimodipine responders \\
\hline
\end{tabular}

Nifedipine

(Dihydropyridine)

\begin{tabular}{ll}
\hline $\begin{array}{l}\text { Eccleston \& Cole } 1990 \\
\text { Moderate to Marked }\end{array}$ & $0 / 1 \mathrm{UP}$ \\
$\begin{array}{l}\text { Responders } \\
\text { Abbreviations: BP = Bipolar Disorder; } \mathrm{M}=\text { Mania; Dep. = Depression; UP = Unipolar; RBD = Recurrent Brief Depression. }\end{array}$ & $125 / 178(70 \%)$ \\
\hline $\begin{array}{l}\text { A Drug-induced hypomania. } \\
{ }^{b} \text { Lithium and nimodipine combination in prophylaxis better than either drug alone. }\end{array}$
\end{tabular}


tients as compared with the placebo phase. Much work remains to delineate the clinical spectrum of efficacy of lamotrigine in refractory affectively ill patients, but the preliminary open observations of Calabrese (1996) and double-blind monotherapy studies of Frye et al. (1998) suggest that this agent could play an important role in the pharmacotherapy of bipolar illness.

\section{GABAPENTIN}

Gabapentin has important effects as an adjunctive treatment of refractory epilepsies and has a variety of purported mechanisms of action with indirect effects on $\gamma$-aminobutyric acid (GABA), such as affecting the GABA transporter and leading to increased levels of GABA in the central nervous system (Beydoun et al. 1995). Its potential for mood stabilization is just beginning to be explored, with preliminary reports of some success (McElroy et al. personal communication, Suppes et al. personal communication, Young et al., 1997) in open clinical observations, and responsivity in 9 of the first 33 patients $(27 \%)$ to be studied in a randomized crossover as compared with placebo and lamotrigine, as noted above (Frye et al. 1998). Because gabapentin is not metabolized in the liver and is excreted in the kidney, and has few pharmacokinetic interactions with other agents, its positive side effects profile and lack of interaction with other drugs makes it a particularly appealing agent for adjunctive therapy, should it prove useful in further clinical trials.

\section{HIGH-POTENCY BENZODIAZEPINES}

The high-potency anticonvulsant benzodiazepines, such as clonazepam and lorazepam, are widely used in the treatment of acute mania and in the anxiety and insomnia of acute depression. The overall antimanic and mood-stabilizing effects of these agents has not yet been adequately delineated (Table 4). However, it is recommended that clinical use proceed with these agents in lieu of neuroleptics (with their liabilities for acute Parkinsonian side-effects and longer-term tardive dyskinesia) for patients with mania, agitation, insomnia, and anxiety breaking-through other treatments.

The increasing use of benzodiazepines is to be encouraged in light of the recent data of Sernyak et al. (1994), who reported that once manic patients are placed on neuroleptics, they are often continued on neuroleptics for extended periods of time, putting patients at greater risk for tardive dyskinesia, which is reported to be a very high 20 to $40 \%$ incidence rate in most studies of patients with bipolar illness (Hunt and Silverstone 1991). Further clinical trials are needed to delineate the acute antimanic efficacy of benzodiazepines in monotherapy, although their adjunctive use, particularly in place of neuroleptics, would seem to have considerable merit, based even on the modicum of preliminary data available.

\section{ATYPICAL NEUROLEPTICS}

The atypical neuroleptics, such as clozapine, are now being used more widely with some success in the treatment of dysphoric mania and rapid cycling (Suppes et al. 1992; Calabrese and Woyshville 1995; Calabrese et al. 1996; Frye et al. 1996). Although seizures are a side effect of clozapine, one study reports that clozapine might have some effects in inhibiting kindled seizure evolution (Graham and Kokkinidis 1993). Denney and Stevens (1995) have also postulated that the microconvulsive properties of clozapine could be related to its profile of clinical efficacy and have noted that patients cotreated with valproate seem to have less robust responses than those who are not so treated. These observations remain to be more systematically documented, but they raise a variety of intriguing possibilities in relation to convulsant and anticonvulsant mechanisms of psychotropic drug action.

Olanzapine and a whole group of atypical neuroleptics (Tamminga and Lahti 1996) are close to FDA approval in addition to risperidone and seroquel, and it is hoped that many of these agents will have positive clozapinelike properties without the liability of blood dyscrasias in the treatment of otherwise refractory bipolar illness.

\section{REPEATED TRANSCRANIAL MAGNETIC STIMULATION (rTMS) OF THE BRAIN}

This modality is just beginning to be explored in the treatment of conventional and refractory depression (Table 5). George et al. (1995) in our group first reported that stimulation with rTMS utilizing $20 \mathrm{~Hz}$ for $20 \mathrm{~min}$ over the left frontal cortex led to improvement in two of the first six patients. This finding led to a randomized design compared with sham, which also showed statistically significant improvement with rTMS (George et al. 1997). These studies were followed by another (Pascual-Leone et al. 1996) reporting 11 of 17 psychotic depressed patients responded to left frontal rTMS but not right frontal cortex or vertex rTMS. Five stimulations in that series led to clinical improvement lasting approximately 2 weeks.

These very exciting preliminary data require further elucidation in order to define the parameters and localities of stimulation that optimally produce antidepressant effects. Because low-frequency stimulation $(1 \mathrm{~Hz}$ for $15 \mathrm{~min}$ ) of the amygdala ("quenching") has dra- 
Table 4. Partially Controlled Studies of Clonazepam and Lorazepam in Acute Mania

\begin{tabular}{|c|c|c|c|c|c|c|}
\hline Study & $N$ & Design & $\begin{array}{c}\text { Addl } \\
\text { Medication }\end{array}$ & Duration & Clon/Lor Doses & Outcome \\
\hline Chouinard et al. (1983) & 11 & $\begin{array}{l}\text { Double-blind crossover } \\
\text { Clon vs. Li }\end{array}$ & Hal & 10 days & $\begin{array}{l}2-16 \mathrm{mg} \text { daily } \\
\text { Flexible }\end{array}$ & Clon $=\mathrm{Li}$ \\
\hline Busch et al. (1989) & 60 & $\begin{array}{l}\text { Retrospective, historical controls } \\
\text { Lor-Cpz vs. Cpz }\end{array}$ & $\begin{array}{l}\mathrm{Li} \\
\mathrm{ECT} \\
\mathrm{CBZ}\end{array}$ & $\begin{array}{c}39 \pm 20 \\
\text { days }\end{array}$ & $\begin{array}{l}310 \mathrm{mg} \mathrm{Cpz}{ }^{b} \text { vs. } \\
1.6 \mathrm{mg} . \text { Lor/day }\end{array}$ & Lor-Cpz $>\mathrm{Cpz}$ \\
\hline Bradwejn et al. (1990) & 24 & $\begin{array}{l}\text { Double-blind } \\
\text { Clon vs. Lor }\end{array}$ & None & 14 days & $\begin{array}{l}6-22 \mathrm{mg} \text { daily } \\
\text { Flexible }\end{array}$ & Lor $>$ Clon \\
\hline Edwards et al. (1991) & 40 & $\begin{array}{l}\text { Double-blind } \\
\text { Clon vs. P }\end{array}$ & Cpz & 5 days & $\begin{array}{l}6 \mathrm{mg} \text { daily } \\
\text { Fixed }\end{array}$ & Clon $>\mathrm{P}$ \\
\hline Lenox et al. (1992) & 20 & $\begin{array}{l}\text { Double-blind lithium plus } \\
\text { Lor or-Hal }\end{array}$ & None & Variable $^{a}$ & $\begin{array}{l}8.8 \pm 4.2 \mathrm{mg} \\
\quad(\text { mean } \pm \mathrm{SE}) \\
\text { Flexible }\end{array}$ & Lor $\approx$ Hal \\
\hline Chouinard et al. (1993) & 35 & $\begin{array}{l}\text { Double-blind Clon vs. Hal } \\
\text { Li after } 1 \text { week }\end{array}$ & None & $\begin{array}{l}14 \text { days, } \\
\text { min }\end{array}$ & $\begin{array}{l}8 \mathrm{mg} \text { daily, initially } \\
\text { Flexible }\end{array}$ & Hal $>$ Clon \\
\hline
\end{tabular}

"a Patients under observation until response or censoring, according to the survival analytical approach.

${ }^{b} \mathrm{Cpz}$ and Lor equivalents used.

Benzodiazepine doses converted to Lor equivalents according to method developed by Hyman and Arana (1987).

Nonbenzodiazepines sedative hypnotics converted to lorazepam equivalents by following method: chloral hydrate $500 \mathrm{mg}=$ pentobarbital $100 \mathrm{mg}=$ lorazepam $1 \mathrm{mg}$ (clinical estimate) (Busch et al. 1989).

Clon, Clonazepam; Lor, Lorazepam; Li, Lithium; Hal, Haloperidol; Cpz, Chlorpromazine; P, Placebo; ECT, Electroconvulsive Therapy; CBZ, Carbamazepine.

matic anticonvulsant effects on kindled seizures (Weiss et al. 1995b), it is possible that low-frequency stimulation may increase inhibition and decrease hyperactivity circuits. However, more recent data indicate that a small direct current of $10-15 \mu \mathrm{A}$ is the critical variable in quenching (Weiss et al., 1998, unpublished data).

Should preliminary observations with the rTMS be supported in subsequent clinical trials, they would have very interesting implications for the mechanism of action of electroconvulsive therapy (ECT), which had always been presumably linked to the generation of a seizure. In rTMS, a seizure is not generated, and there are no subjective reports of cognitive clouding or impairment similar to that often induced with ECT. It is possible that rTMS is more directly engaging the mechanism generated after a ECT seizure and that these rTMS effects are related to its potential clinical antidepressant profile. The molecular mechanisms require further elucidation, but the clinical and research potential for rTMS in discretely stimulating areas of the brain remains an exciting frontier.

\section{CONCLUSION}

Two decades ago lithium, as supplemented by neuroleptics and antidepressants, was virtually the only putative mood-stabilizing agent available for bipolar ill-

Table 5. Repeated Transcranial Magnetic Stimulation (rTMS) in Affective Illness

\begin{tabular}{|c|c|c|c|c|c|c|}
\hline Patients & Design & Duration & Frequency & $\begin{array}{l}\text { \% Motor } \\
\text { Threshold }\end{array}$ & Location & Response \\
\hline $\begin{array}{l}\text { Refractory depressed } \\
\text { (George et al. 1995) }\end{array}$ & Open & 5 Days & $20 \mathrm{~Hz}$ & $80 \%$ & Left frontal & 2 of 6 Responded \\
\hline $\begin{array}{l}\text { Psychotic depresed } \\
\text { (Pascual-Leone } \\
\text { et al. 1996) }\end{array}$ & Sham vs. region & 5 Days & $10 \mathrm{~Hz}$ & $90 \%$ & $\begin{array}{l}\text { Left frontal, right } \\
\text { frontal, and } \\
\text { occipital }\end{array}$ & $\begin{array}{l}11 \text { of } 17 \text { Responded to left } \\
\text { frontal stimulation }\end{array}$ \\
\hline $\begin{array}{l}\text { Psychotic depressed } \\
\text { (Catalá et al. 1996) }\end{array}$ & Left vs. right & 2 Weeks & $10 \mathrm{~Hz}$ & $110 \%$ & $\begin{array}{l}\text { Left and right } \\
\text { prefrontal }\end{array}$ & $\begin{array}{l}7 \text { of } 7 \text { Improved with left, } \\
\text { but not right stimulation }\end{array}$ \\
\hline $\begin{array}{l}\text { Depressed outpatients } \\
\text { (George et al. 1997) }\end{array}$ & $\begin{array}{l}\text { Sham vs. active } \\
\text { crossover }\end{array}$ & 2 Weeks & $20 \mathrm{~Hz}$ & $80 \%$ & Left frontal & $\begin{array}{l}\text { Significant improvement } \\
\text { over sham }(N=12)\end{array}$ \\
\hline $\begin{array}{c}\text { Depressed inpatients } \\
\text { (Kimbrell et al. 1998, } \\
\text { unpublished data) }\end{array}$ & $\begin{array}{l}\text { Sham vs. } \\
\text { frequency }\end{array}$ & 10 Days & $\begin{array}{l}1 \mathrm{~Hz} \text { vs. } 20 \\
\mathrm{~Hz}\end{array}$ & $80 \%$ & Left frontal & $\begin{array}{l}\text { Opposite effects in } \\
\text { different patients }\end{array}$ \\
\hline $\begin{array}{l}\text { Depressed inpatients } \\
\text { (George et al. 1998, } \\
\text { unpublished data) }\end{array}$ & $\begin{array}{l}\text { Sham vs. } \\
\text { frequency }\end{array}$ & 2 Weeks & $\begin{array}{l}5 \mathrm{~Hz} \text { vs. } 20 \\
\mathrm{~Hz}\end{array}$ & $80 \%$ & Left frontal & In progress \\
\hline
\end{tabular}


ness. Increasingly, it has been recognized that lithium alone or in combination with adjunctive strategies is inadequate for a very substantial group of bipolar patients. Now a variety of putative mood-stabilizing agents are available for acute and long-term therapeutics and for devising the optimal treatment algorithms in the most appropriate combination. The sequencing of these agents remains a very important issue for further clinical work and systematic clinical trials in methodological exploration. Over each of the last five 5-year epochs at the National Institute for Mental Health (NIMH), we have found that approximately $80 \%$ of our patients were able to be discharged with marked or moderate improvement. Twenty years ago, three-quarters of the patients were discharged from our clinical research unit on monotherapy; in the last 5-year epoch, only $25 \%$ of the patients were discharged on monotherapy, and the average was 3 drugs per patient. Thus, rational combination therapy seems to be a requirement for clinical stabilization in many instances (Frye 1996). Defining the principles for optimum combination of these agents (Post et al. 1996b; Post et al. 1997) remains a very important task for future research.

\section{REFERENCES}

Aagaard J, Vestergaard P (1990): Predictors of outcome in prophylactic lithium treatment: A 2-year prospective study. J Aff Dis 18:259-266

Ballenger JC, Post RM (1978): Therapeutic effects of carbamazepine in affective illness: Preliminary report. Commun Psychopharmacol 2:159-175

Ban TA, Morey L, Aguglia E, Azzarelli O, Balsano F, Marigliano V, Caglieris N, Sterlicchio M, Capurso A, Tomasi NA (1990): Nimodipine in the treatment of old age dementias. Prog Neuropsychopharmacol Biol Psych 14:525-551

Barton BM, Gitlin MJ (1987): Verapamil in treatment-resistant mania: An open trial. J Clin Psychopharmacol 7:101-103

Bellaire W, Demisch K, Stoll K-D (1990): Carbamazepine vs. Lithium. Application in the Prophylaxis of Recurrent Affective and Schizoaffective Psychoses. Munch Med Wschr 132:S82-S86

Beydoun A, Uthman BM, Sackellares JC (1995): Gabapentin: Pharmacokinetics, efficacy, and safety. Clin Neuropharm 18:469-481

Bowden CL, Brugger AM, Swann AC, Calabrese JR, Janicak PG, Petty F, Dilsaver SC, Davis JM, Rush AJ, Small JG, Garza-Trevino ES, Risch SC, Goodnick PJ, Morris DD (1994): Efficacy of divalproex vs. lithium and placebo in the treatment of mania. JAMA 271:918-924

Bowden CL, Janicak PG, Orsulak P, Swann AC, Davis JM, Calabrese JR, Goodnick P, Small JG, Rush AJ, Kimmel SE, Risch SC, Morris DD (1996): Relation of serum valproate concentration to response in mania. Am J Psychiat 153:765-770
Bradwejn J, Shriqui C, Koszycki D, Meterissian G (1990): Double-blind comparison of the effects of clonazepam and lorazepam in acute mania. J Clin Psychopharmacol 10:403-408

Brodie MJ, Richens A, Yuen AW (1995): Double-blind comparison of lamotrigine and carbamazepine in newly diagnosed epilepsy. UK Lamotrigine/Carbamazepine Monotherapy Trial Group. Lancet 345:476-479

Brotman AW, Farhadi AM, Gelenberg AJ (1986): Verapamil treatment of acute mania. J Clin Psychiat 47:136-138

Brown D, Silverstone T, Cookson J (1989): Carbamazepine compared to haloperidol in acute mania. Int Clni Psychopharmacol 4:229-238

Brunet G, Cerlich B, Robert P, Dumas S, Souetre E, Darcourt G (1990): Open trial of a calcium antagonist, nimodipine in acute mania. Clin Neuropharmacol 13:224-228

Busch FN, Miller FT, Weiden PJ (1989): A comparison of two adjunctive treatment strategies in acute mania. J Clin Psychiat 50:453-455

Cabrera JF,Muhlbauer HD, Schley J, Stoll KD, Muller-Oerlinghausen B (1986): Long-term randomized clinical trial on oxcarbazepine vs. lithium in bipolar and schizoaffective disorders: Preliminary results. Pharmacopsychiatry 19:282-283

Caillard V (1985): Treatment of mania using a calcium antagonist-Preliminary trial. Neuropsychobiology 14:23-26

Calabrese JR, Delucchi GA (1989): Phenomenology of rapid cycling manic depression and its treatment with valproate. J Clin Psychiat 50:30-34

Calabrese JR, Delucchi GA (1990): Spectrum of efficacy of valproate in 55 patients with rapid-cycling bipolar disorder. Am J Psychiat 147:431-434

Calabrese JR, Markovitz PJ, Kimmel SE, Wagner SC (1992): Spectrum of efficacy of valproate in 78 rapid-cycling bipolar patients. J Clin Psychopharmacol 12:53S-56S

Calabrese JR, Woyshville MJ (1995): A medication algorithm for treatment of bipolar rapid cycling? J Clin Psychiatry 56 (Suppl 3):11-18

Calabrese C (1996): Lamotrigine in treatment refractory manic depression. J Eur College Neuropsychopharmacology 6:98

Calabrese JR, Kimmel SE, Woyshville MJ, Rapport DJ, Faust CJ, Thompson PA, Meltzer HY (1996): Clozapine for treatment-refractory mania. Am J Psychiat 153:759-764

Catalá MD, Rubio B, Pascual-Leone A (1996): Lateralized effect of rapid-rate transcranial magnetic stimulation of dorsolateral prefrontal cortex on depression. Neurology 46:A327 (abstract \#S28.005)

Chouinard G, Young SN, Annable L (1983): Antimanic effect of clonazapam. Biol Psychiat 18:451-466

Chouinard G, Annable L, Turnier L, Holobow N, Szkrumelak N (1993): A double-blind randomized clinical trial of rapid tranquilization with I.M. clonazepam and I.M. haloperidol in agitated psychotic patients with manic symptoms. Can J Psychiat 38:S114-S121

Coxhead N, Silverstone T, Cookson J (1992): Carbamazepine versus lithium in the prophylaxis of bipolar affective disorder. Acta Psychiat Scand 85:114-118

Deicken RF (1990): Verapamil treatment of bipolar depression. J Clin Psychopharmacol 10:148-149 
Denicoff KD, Smith-Jackson EE, Disney ER, Ali SO, Leverich GS, Post RM (1997): Comparative prophylactic efficacy of lithium, carbamazepine, and the combination in bipolar disorder. J Clin Psychiatry 58:470-478

Denney D, Stevens JR (1995): Clozapine and seizures. Biol Psychiat 37:427-433

Desai NG, Gangadhar BN, Channabasavanna SM, Shetty KT (1987): Carbamazepine hastens therapeutic action of lithium in mania. Proceedings of the International Conference on New Directions in Affective Disorders, 97

Di Costanzo E, Schifano F (1991): Lithium alone or in combination with carbamazepine for the treatment of rapidcycling bipolar affective disorder. Acta Psychiat Scand 83:456-459

Dose M, Emrich HM, Cording-Tommel C, Von Zerssen D (1986): Use of calcium antagonists in mania. Psychoneuroendocrinology 11:241-243

Dubovsky SL, Franks RD, Lifschitz M, Coen P (1982): Effectiveness of verapamil in the treatment of a manic patient. Am J Psychiat 139:502-504

Dubovsky SL, Franks RD (1983): Intracellular calcium in affective disorders: A review and an hypothesis. Biol Psychiat 18:781-797

Dubovsky S, Franks R, Schrier D (1985): Phenelzine-induced hypomania: Effect of verapamil. Biol Psychiat 20:10091014

Dubovsky SL, Franks RD, Allen S (1986): Calcium antagonists in mania: A double-blind study of verapamil. Psychiat Res 18:309-320

Dubovsky SL, Franks RD (1987): Verapamil: A new antimanic drug with potential interactions with lithium. J Clin Psychiat 48:371-372

Eccleston D, Cole AJ (1990): Calcium-channel blockade and depressive illness. Br J Psychiat 156:889-891

Eckmann F (1985a): Clinical studies on nimodipine in the treatment of patients with depressive syndromes in the second half of life. In Betz E, Deck K, Hoffmeister F (eds), Nimodipine: Pharmacological and Clinical Studies. Stuttgart, Schattauer, pp 307-313

Eckmann VF (1985b): Double-blind clinical study with the calcium antagonist flunarizine in cerebral circulatory disturbances. Arzneimittelforschung 35:1276-1279

Edwards R, Stephenson U, Flewett T (1991): Clonazepam in acute mania: A double-blind trial. Aust N Z J Psychiat 25:238-242

Elphick M, Lyons F, Cowen PJ (1988): Low tolerability of carbamazepine in psychiatric patients may restrict its clinical usefulness. J Psychopharmacol 2:1-4

Emrich HM, Dose M, Von Zerssen D (1984): Action of sodium-valproate and of oxcarbazepine in patients with affective disorders. In Emrich HM, Okuma T, Muller AA (eds), Anticonvulsants in Affective Disorders. Amsterdam, Excerpta Medica, pp 45-55

Emrich HM, Dose M, Von Zerssen D (1985): The use of sodium valproate, carbamazepine, and oxcarbazepine in patients with affective disorders. J Aff Dis 8:243-250

Emrich HM (1990): Studies with oxcarbazepine (Trileptal) in acute mania. Int Clin Psychopharmacol 5:83-88

Fawcett J (1988): Personal Communication, March
Frankenburg FR, Tohen M, Cohen BM, Lipinski JF, Jr. (1988): Long-term response to carbamazepine: A retrospective study. J Clin Psychopharmacol 8:130-132

Freedman DD, Waters DD (1987): 'Second generation' dihydropyridine calcium antagonists. Greater vascular selectivity and some unique applications. Drugs 34:578-598

Fromm GH, Terrence CF (1987): Effects of antiepileptic drugs on the brain-stem. In Fromm GH, Faingold CL, Browning RA, Burnham WM (eds), Epilepsy and the Reticular Formation. New York, Alan R. Liss, pp 119-136

Frye MA (1996): The increasing use of polypharmacy for refractory mood disorders: Twenty-five years of study (abstract). APA New Research Program and Abstracts, pp 151-152 (abstract NR312)

Frye MA, Altshuler LL, Bitran J (1996): Clozapine in rapid cycling bipolar disorder. J Clin Psychopharmacol 16:87-90

Frye MA, Ketter TA, Kimbrell TA, Dunn RM, Speer AM, Osuch EA, Luckenbaugh D, Cora-Locatelli G, Leverich GS, Post RM (1998): Gabapentin and lamotrigine monotherapy in mood disorder (abstract). Syllabus and Proceedings Summary of the 151st Meeting of the American Psychiatric Association (in press).

Garza-Trevino ES (1990): Verapamil versus lithium in acute mania. Abstracts of the 143rd Annual Meeting of the American Psychiatric Association: 78 (abstract \#27)

Garza-Trevino ES, Overall JE, Hollister LE (1992): Verapamil versus lithium in acute mania. Am J Psychiat 149:121-122

Gelenberg AJ, Kane JM, Keller MB, Lavori P, Rosenbaum JF, Cole K, Lavelle J (1989): Comparison of standard and low serum levels of lithium for maintenance treatment of bipolar disorder. N Engl J Med 321:1489-1493

George MS, Wassermann EM, Williams WA, Callahan A, Ketter TA, Basser P, Hallett M, Post RM (1995): Daily repetitive transcranial magnetic stimulation (rTMS) improves mood in depression. NeuroReport 6:1853-1856

George MS, Wassermann EM, Williams WA, Kimbrell TA, Little JT, Hallett M, Post RM (1996): Daily left prefrontal repetitive transcranial magnetic stimulation in outpatient depression: Initial results of a double-blind placebo controlled crossover trial (abstract). APA New Research Program and Abstracts: 280 (abstract NR768)

George MS, Wassermann EM, Kimbrell TA, Little JT, Williams WE, Danielson AL, Greenberg BD, Hallett M, Post RM (1997): Mood improvement following daily left prefrontal repetitive transcranial magnetic stimulation in patients with depression: A placebo-controlled crossover trial. Am J Psychiatry 154:1752-1756

Giannini AJ, House WL, Loiselle RH (1984): Antimanic effects of verapamil. Am J Psychiat 141:1602-1603

Giannini AJ, Taraszewski R, Loiselle RH (1987): Verapamil and lithium in maintenance therapy of manic patients. J Clin Pharmacol 27:980-982

Giannini AJ, Sullivan BS, Folts DJ (1989): Comaprison of lithium carbonate, valproic acid and verapamil in the treatment of manic symptoms. J Clin Pharmacol 29:832 (abstract \#1)

Gitlin MJ, Weiss J (1984): Verapamil as maintenance treatment in bipolar illness: a case report. J Clin Psychopharmacol 4:341-343

Gitlin MJ, Swendsen J, Heller TL, Hammen C (1995): Relapse 
and impairment in bipolar disorder. Am J Psychiat 152:1635-1640

Goncalves N, Stoll KD (1985): Carbamazepine in manic syndromes. A controlled double-blind study. Nervenarzt 56:43-47

Goodnick PJ (1995): Nimodipine treatment of rapid cycling bipolar disorder. J Clin Psychiat 56:330

Graham SR, Kokkinidis L (1993): Clozapine inhibits limbic system kindling: Implications for antipsychotic action. Brain Res Bull 30:597-605

Greil W, Ludwig-Mayerhofer W, Erazo N, Schochlin C, Schmidt S, Engel RR, Czernic A, Giedke H, Müller-Oerlinghausen B, Osterheider M, Rudolf GA, Sauer H, Tegeler J, Wetterling T (1997a): Lithium versus carbamazepine in the maintenance treatment of bipolar disorders - a randomised study. J Affect Disord 43:151-161

Greil W, Ludwig-Mayerhofer W, Erazo N, Engel RR, Czernik A, Giedke H, Müller-Oerlinghausen B, Osterheider M, Rudolf GA, Sauer H, Tegeler J, Wetterling T (1997b): Lithium vs carbamazepine in the maintenance treatment of schizoaffective disorder: A randomised study. Eur Arch Psychiatry Clin Neurosci 247:42-50

Grossi E, Sacchetti E, Vita A, Conte G, Faravelli C, Hautmann G, Zerbi D, Mesina AM, Drago F, Motta A (1984): Carbamazepine vs. chlorpromazine in mania: A doubleblind trial. In Emrich HM, Okuma T, Muller AA (eds), Anticonvulsants in Affective Disorders. Amsterdam, Excerpta Medica, pp 177-187

Grunze H, Walden J, Wolf R, Berger M (1996): Combined treatment with lithium and nimodipine in a bipolar I manic syndrome. Prog Neuropsychopharmacol Biol Psychiat 20:419-426

Hoschl C (1983): Verapamil for depression? Am J Psychiat 140:1100

Hoschl C, Kozeny J (1989): Verapamil in affective disorders: A controlled, double-blind study. Biol Psychiat 25:128-140

Hoschl C, Vackova J, Janda B (1992): Mood stabilizing effect of verapamil. Bratisl Lek Listy 93:208-209

Hunt N, Silverstone T (1991): Tardive dyskinesia in bipolar affective disorder: A catchment area study. Int Clin Psychopharmacol 6:45-50

Hyman SE, Arana GW (1987): Handbook of Psychiatric Drug Therapy. Boston, Little Brown

Janicak PG, Pandey G, Sharma R, Peterson J, Leach A, Davis JM (1994): Verapamil for actue mania: Preliminary results from a double-blind, placebo-controlled study (abstract). Proceedings of 1st International Conference on Bipolar Disorder, 46

Keck PE Jr, McElroy SL, Tugrul KC, Bennett JA (1993): Valproate oral loading in the treatment of acute mania. J Clin Psychiat 54:305-308

Ketter TA, Kimbrell TA, George MS, Stein RM, Willis MW, Benson BE, Frye MA, Cora-Locatelli G, Post RM (1996): Baseline hypermetabolism may predict carbamazepine response and hypometabolism nimodipine response in mood disorders. Abstracts of the XXth Collegium Internationale Neuro-Psychopharmacologicum Congress:10 (abstract \#O-5-6)

Kishimoto A, Okuma T (1986): Antimanic and prophylactic effects of carbamazepine in affective disorders. In Sha- gass C, Josiassen RC, Bridger WH, Weiss KJ, Stoff D, Simpson GM (eds), Biological Psychiatry 1985. Amsterdam, Elsevier, pp 883-885

Klein E, Bental E, Lerer B, Belmaker RH (1984): Carbamazepine and haloperidol vs. placebo and haloperidol in excited psychoses. Arch Gen Psychiat 41:165-170

Koukopoulos A, Reginaldi D, Minnai G, Serra G, Pani L, Johnson FN (1995): The long-term prophylaxis of affective disorders. Adv Biochem Psychopharmacol 49:127-147

Lambert PA (1984): Acute and prophylactic therapies of patients with affective disorders using valpromide (dipropylacetamide). In Emrich HM, Okuma T, Muller AA (eds), Anticonvulsants in Affective Disorders. Amsterdam, Excerpta Medica, pp 33-44

Lambert PA, Venaud G (1995): Comparative study of valpromide vs.lithiumas prophylactic treatments in affective disorders. Nervure J Psychiatrie 1-9

Lenox RH, Newhouse PA, Creelman WL, Whitaker TM (1992): Adjunctive treatment of manic agitation with lorazepam versus haloperidol: A double-blind study. J Clin Psychiat 53:47-52

Lenzi A, Lazzerini F, Grossi E, Massimetti G, Placidi GF (1986): Use of carbamazepine in acute psychosis: A controlled study. J Int Med Res 14:78-84

Lerer B, Moore N, Meyendorff E, Cho SR, Gershon S (1987): Carbamazepine versus lithium in mania: A doubleblind study. J Clin Psychiat 48:89-93

Lindelius R, Nilsson CG (1992): Flunarizine as maintenance treatment of a patient with bipolar disorder. Am J Psychiat 149:139

Lusznat RM, Murphy DP, Nunn CM (1988): Carbamazepine vs. lithium in the treatment and prophylaxis of mania. Br J Psychiat 153:198-204

Maj M, Pirozzi R, Kemali D (1989): Long-term outcome of lithium prophylaxis in patients initially classified as complete responders. Psychopharmacology (Berlin) 98: 535-538

Manna V (1991): Bipolar affective disorders and role of intraneuronal calcium. Therapeutic effects of the treatment with lithium salts and/or calcium antagonist in patients with rapid polar inversion. Minerva Med 82:757-763

McDermut W, Pazzaglia PJ, Huggins T, Mikalauskas K, Leverich GS, Ketter TA, Bartko J, Post RM (1995): Use of single case analyses in off-on-off-on trials in affective illness: A demonstration of the efficacy of nimodipine. Depression 2:259-271

Messenheimer JA (1995): Lamotrigine. Epilepsia 36:S87-S94

Moller HJ, Kissling W, Riehl T, Bauml J, Binz U, Wendt G (1989): Double-blind evaluation of the antimanic properties of carbamazepine as a comedication to haloperidol. Prog Neuropsychopharmacol Biol Psychiat 13:127-136

Montenegro R, Comide E, Castro JM (1985): Nimodipine in the treatment of involutional depressive syndrome. In Betz E, Deck K, Hoffmeister F (eds), Nimodipine: Pharmacological and Clinical Studies. Stuttgart, Schattauer, pp 307-313

Mosolov SN (1991): Comparative effectiveness of preventive use of lithium carbonate, carbamazepine and sodium valproate in affective and schizoaffective psychoses. $\mathrm{Zh}$ Nevropatol Psikhiatr 91:78-83

Muller AA, Stoll K-D (1984): Carbamazepine and oxcarbam- 
azepine in the treatment of manic syndromes: studies in Germany. In Emrich HM, Okuma T, Muller AA (eds), Anticonvulsants in Affective Disorders. Amsterdam, Excerpta Medica, pp 139-147

O'Connell RA, Mayo JA, Flatow L, Cuthbertson B, O'Brien BE (1991): Outcome of bipolar disorder on long-term treatment with lithium. Br J Psychiat 159:123-129

Okuma T, Inanaga K, Otsuki S, Sarai K (1979): Comparison of the antimanic efficacy of carbamazepine and chlorpromazine: A double-blind controlled study. Psychopharmacology 66:211-217

Okuma T, Inanaga K, Otsuki S, Sarai K, Takahashi R, Hazama H, Mori A, Watanabe M (1981): A preliminary double-blind study of the efficacy of carbamazepine in prophylaxis of manic-depressive illness. Psychopharmacology 73:95-96

Okuma T, Yamashita I, Takahashi R, Itoh H, Kurihara M, Otsuki S, Watanabe S, Sarai K, Hazama H, Inangana K (1988): Double-blind controlled studies on the therapeutic efficacy of carbamazepine in affective and schizophrenic patients. Psychopharmacology 96:102 (abstract \#TH18.05)

Okuma T, Yamashita I, Takahashi R, Itoh H, Otsuki S, Watanabe S, Sarai K, Hazama H, Inananga K (1990): Comparison of the antimanic efficacy of carbamazepine and lithium carbonate by double-blind controlled study. Pharmacopsychiatry 23:143-150

Okuma T (1993): Effects of carbamazepine and lithium on affective disorders. Neuropsychobiology 27:138-145

Pani L, Kuzmin A, Diana M, De Montis G, Gessa GL, Rossetti ZL (1990): Calcium receptor antagonists modify cocaine effects in the central nervous system differently. Eur J Pharmacol 190:217-221

Pascual-Leone A, Rubio B, Pallardo F, Catala MD (1996): Rapid-rate transcranial magnetic stimulation of left dorsolateral prefrontal cortex in drug-resistant depression. Lancet 348:233-237

Patterson JF (1987): Treatment of acute mania with verapamil. J Clin Psychopharmacol 7:206-207

Pazzaglia PJ, Post RM (1992): Contingent tolerance and reresponse to carbamazepine: A case study in a patient with trigeminal neuralgia and bipolar disorder. J Neuropsychiat Clin Neurosci 4:76-81

Pazzaglia PJ, Post RM, Ketter TA, George MS, Marangell LB (1993): Preliminary controlled trial of nimodipine in ultra-rapid cycling affective dysregulation. Psychiat Res 49:257-272

Pazzaglia PJ, Post RM, Ketter TA, Callahan AM, Marangell LB, Frye MA, George MS, Kimbrell TA, Leverich GS, Cora-Locatelli G, Luckenbaugh D (1998): Nimodipine monotherapy and carbamazepine augmentation in patients with refractory recurrent affective illness. J Clin Psychopharmacol (in press)

Placidi GF, Lenzi A, Lazzerini F, Cassano GB, Akiskal HS (1986): The comparative efficacy and safety of carbamazepine versus lithium: A randomized, double-blind 3year trial in 83 patients. J Clin Psychiat 47:490-494

Pollack MH, Rosenbaum JF (1987): Verapamil in the treatment of recurrent unipolar depression. Biol Psychiat 22:779-782

Pope HG, McElroy SL, Keck PE, Jr., Hudson JI (1991): Val- proate in the treatment of acute mania. Arch Gen Psychiat 48:62-68

Post RM, Uhde TW, Ballenger JC, Squillace KM (1983): Prophylactic efficacy of carbamazepine in manic-depressive illness. Am J Psychiat 140:1602-1604

Post RM, Ballenger JC, Uhde TW, Bunney WEJ (1984a): Efficacy of carbamazepine in manic-depressive illness: Implications for underlying mechanisms. In Post RM, Ballenger JC (eds), Neurobiology of Mood Disorders. Baltimore, Williams \& Wilkins, pp 777-816

Post RM, Berrettini WH, Uhde TW, Kellner CH (1984b): Selective response to the anticonvulsant carbamazepine in manic-depressive illness: A case study. J Clin Psychopharmacol 4:178-185

Post RM, Uhde TW, Roy-Byrne PP, Joffe RT (1986): Antidepressant effects of carbamazepine. Am J Psychiat 143: 29-34

Post RM, Uhde TW, Roy-Byrne PP, Joffe RT (1987): Correlates of antimanic response to carbamazepine. Psychiat Res 21:71-83

Post RM (1989): Use of anticonvulsants in the treatment of manic-depressive illness. In Post RM, Trimble MR, Pippenger CE (eds), Clinical Use of Anticonvulsants in Psychiatric Disorders. New York, Demos Publications, pp 113-152

Post RM, Leverich GS, Rosoff AS, Altshuler LL (1990): Carbamazepine prophylaxis in refractory affective disorders: A focus on long-term follow-up. J Clin Psychopharmacol 10:318-327

Post RM, Leverich GS, Altshuler L, Mikalauskas K (1992): Lithium discontinuation-induced refractoriness: Preliminary observations. Am J Psychiat 149:1727-1729

Post RM, Leverich GS, Pazzaglia PJ, Mikalauskas K, Denicoff K (1993): Lithium tolerance and dicontinuation as pathways to refractoriness. In Birch NJ, Padgham C, Hughes MS (eds), Lithium in Medicine and Biology. Lancashire, UK, Marius Press, pp 71-84

Post RM, Ketter TA, Pazzaglia PJ, Denicoff K, Marangell L, George MS (1994): Anticonvulsants in refractory mood disorders. In Nolen WA, Zohar J, Roose SP (eds), Refractory Depression: Current Strategies and Future Directions. Chichester, England, John Wiley \& Sons, pp 97-114

Post RM, Ketter TA, Denicoff K, Pazzaglia PJ, Leverich GS, Marangell LB, Callahan AM, George MS, Frye MA (1996a): The place of anticonvulsant therapy in bipolar illness. Psychopharmacology (Berlin) 128:115-129

Post RM, Ketter TA, Pazzaglia PJ, Denicoff K, George MS, Callahan A, Leverich G, Frye M (1996b): Rational polypharmacy in the bipolar affective disorders. Epilepsy Res 11 (suppl):153-180

Post RM, Denicoff KD, Frye MA, Leverich GS (1997): Algorithms for bipolar mania. In Rush AJ (ed), Mood Disorders. Systematic Medication Management. Basel, Karger, pp 114-145

Prien RF, Gelenberg AJ (1989): Alternatives to lithium for preventive treatment of bipolar disorder. Am J Psychiat 146:840-848

Roy-Byrne PP, Joffe RT, Uhde TW, Post RM (1984): Carbamazepine and thyroid function in affectively ill patients: Clinical and theoretical implications. Arch Gen Psychiat 41:1150-1153 
Sarantidis D, Waters B (1981): Predictors of lithium prophylaxis effectiveness. Prog Neuropsychopharmacol 5:507510

Schaff MR, Fawcett J, Zajecka JM (1993): Divalproex sodium in the treatment of refractory affective disorders. J Clin Psychiat 54:380-384

Sernyak MJ, Griffin RA, Johnson RM, Pearsall HR, Wexler BE, Woods SW (1994): Neuroleptic exposure following inpatient treatment of acute mania with lithium and neuroleptic. Am J Psychiat 151:133-135

Small JG, Klapper MH, Milstein V, Kellams JJ, Miller MJ, Marhenke JD, Small IF (1991): Carbamazepine compared with lithium in the treatment of mania. Arch Gen Psychiat 48:915-921

Solomon I, Williamson P (1986): Verapamil in bipolar illness. Can J Psychiat 31:442-444

Stoll KD, Bisson HE, Fischer E, Gammel G, Goncalves N, Krober HL, Muldner H, Nadler A, Troyke P (1986): Carbamazepine versus haloperidol in manic syndromesFirst report of a multicentric study in Germany. In Shagass C, Josiassen RC, Bridger WH, Weiss KJ, Stoff D, Simpson GM (eds), Biological Psychiatry 1985. Amsterdam, Elsevier, pp 332-334

Suppes T, McElroy SL, Gilbert J, Dessain EC, Cole JO (1992): Clozapine in the treatment of dysphoric mania. Biol Psychiat 32:270-280

Svestka J, Nahunek K, Ceskova E, Korbicka J (1985): Carbamazepine prophylaxis of affective psychoses (intraindividual comparison with lithium carbonate). Activ Nerv Sup 27:261-262

Tamminga CA, Lahti AC (1996): The new generation of antipsychotic drugs. Int Clin Psychopharmacol 11:73-76
Triggle DJ (1992): Biochemical and pharmacologic differences among calcium channel antagonists: Clinical implications. In Epstein M (ed), Calcium Antagonists in Clinical Medicine. Philadelphia, Hanley \& Belfus, pp 1-27

Vestergaard P (1992): Treatment and prevention of mania: A Scandinavian perspective. Neuropsychopharmacology $7: 249-260$

Walden J, Grunze H, Hellhammer D, Fritze J, Berger M (1994): Treatment of depressive episodes with the calcium antagonist nimodipine: Single case reports. Neuropsychopharmacology 10:233S.

Walton SA, Berk M, Brook S (1996): Superiority of lithium over verapamil in mania: A randomized conrolled trial. J Eur College Neuropsychopharmacol 6:9-10

Watkins SE, Callender K, Thomas DR, Tidmarsh SF, Shaw DM (1987): The effect of carbamazepine and lithium on remission from affective illness. Br J Psychiat 150:180-182

Weiss SRB, Clark M, Rosen JB, Smith MA, Post RM (1995a): Contingent tolerance to the anticonvulsant effects of carbamazepine: Relationship to loss of endogenous adaptive mechanisms. Brain Res Rev 20:305-325

Weiss SRB, Li XL, Rosen JB, LiH, Heynen T, Post RM (1995b): Quenching: Inhibition of development and expression of amygdala kindled seizures with low frequency stimulation. NeuroReport 6:2171-2176

Wolf C, Berky M, Kovacs G (1997): Carbamazepine versus lithium in the prophylaxis of bipolar affective disorders: A randomised, double-blind 1-year study in 168 patients (abstract). Eur Neuropsychopharmacol 7(suppl. 2):S176

Young LT, Robb JC, Patelis-Siotis I, MacDonald C, Joffe RT (1997): Acute treatment of bipolar depression with garapentin. Biol Psychiat 42:851-853 